\title{
1201 鋼索の電磁探傷における張力の影響について
}

\section{1. 緒言}

鋼索の使用状況は千差万別であるから，鋼索を電磁的 に探賃するにあたつてはその状況に㐫して考慮を払わな 讨ればならない問題が岁る。われわれは先に交流励磁し た鋼索の周りに巻いたコイルの誘起電圧が鋼索の有效断

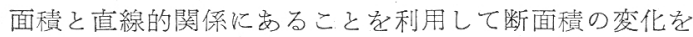
検出する装置*を発表した。

強硫性体である鋼索に応力を加光歪が生じると，その 磁化状態が变化する。したがつて，電嗞的に鋼索を検查 する場合，応力の影響を舤視することはできない。とこ ろが，鋼索に作用する応力は複雑であり，末たその化学 組成も一定でないため，張力が磁化に及伎す影響の理論 的な解析は難しい問題で岕る。 そこで，われわれはおず実測し た結果をここ報告する。

\section{2. 実験装置および試料}

励磁コイルは第1図のように 珪素鋼板によつて試料を一辺と する閉磁路を棈成するむので， 磁化した鋼索にアムスラ試験機 で張力を加えて誘起電圧を測定 した。な拈, 励磁電流は60cycle /secを用いた。さらに，磁化状 態の変化による励磁コイルのイ

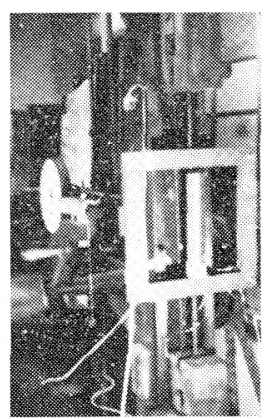

第 1 図 実験装置

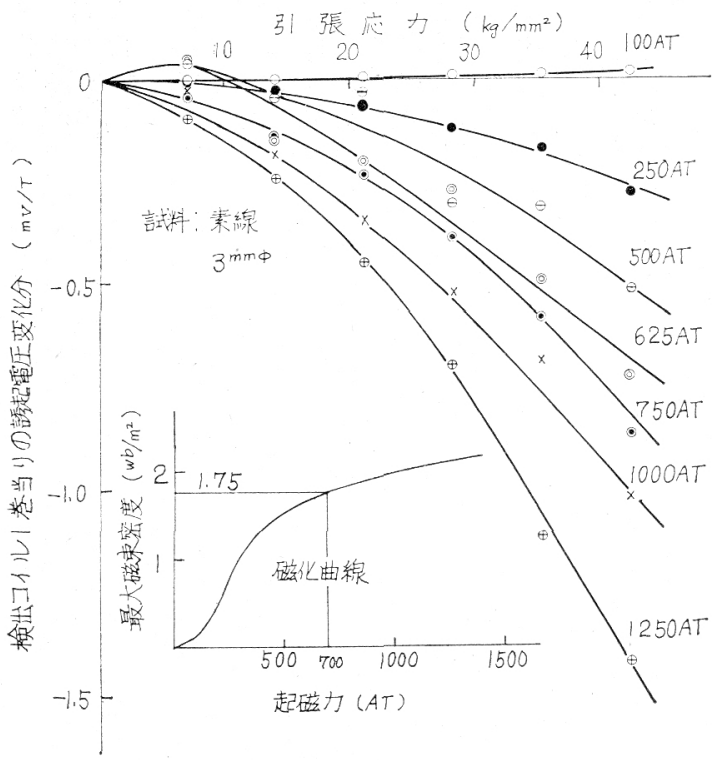

第 2 図 素線の引張応力による誘起䉓圧の変化（付 素線の磁化曲線）

$\begin{array}{rrrll}\text { 九州工業大学教授・工博 } & \text { 秋 } & \text { 吉 } & \text { 利 } & \text { 男(正会員) } \\ \text { 九州工業大学助手 } & \text { ○佐 } & \text { 木 } & \text { 昭 } & \text { 士(正会員) } \\ \text { 九州工業大学大学院学生 } & \text { 山 } & \text { 本 } & \text { 秀 } & \text { 俊 }\end{array}$

ンピーダンスの変化を打消すためにコイルに直列に抵抗 を結線した。

実験試料は第1表のようなりのを用いた。

\section{3. 実 験 結 果}

素線：磁化した素線に張力を加えた場合の誘起電圧の

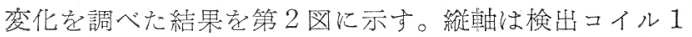
回当りの誘起電圧（尖頭值）の変化值であり，また横軸 は引張応力で岕る。困から，初期透磁率の磁化状態すな わち $100 \mathrm{AT}$ 付近のものでは引張応力の增加とともに誘 起電圧は增加し, さらに強い磁化状態になるに従つてす なわち $250 \mathrm{~A}$ T 以上になると逆に引張応力の增加々とも に滅少している。一方, 漏洩磁束による断線などの局部欠 陷検出に望しい磁場の強さすなわ見掛け上の飽和点**

(ここでは $700 \mathrm{AT}$ ) 近くでは引張応力の増加とともに 誘起電王は一般的に減少している。

鋼索：試料 No. $2 ， 3$ 特よび 4 の鋼索に張力を加えた 場合の誘起電圧の減少の割合をそれぞれ第 3,4 扤よび 5

\begin{tabular}{|c|c|c|c|c|c|}
\hline $\begin{array}{l}\text { 試料 } \\
\text { 番号 }\end{array}$ & 種 & 棈＼cjkstart造 & 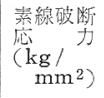 & $\left|\begin{array}{c}\text { 有效断面䖽 } \\
\left(\mathrm{mm}^{2}\right)\end{array}\right|$ & 備 考 \\
\hline $\begin{array}{l}\text { No. } 1 \\
\text { No. } 2 \\
\text { No. } 3\end{array}$ & $\begin{array}{l}\text { 菜線 } \\
\text { ストルロープ } \\
\text { ストラシデッドロープ }\end{array}$ & $\begin{array}{l}1+6 \\
6 \times 7\end{array}$ & $\begin{array}{l}185 \\
165 \\
165\end{array}$ & $\begin{array}{l}7.065 \\
69.14 \\
81.60\end{array}$ & $\begin{array}{l}3 \mathrm{~mm} \phi \\
10 \mathrm{~mm} \phi \\
14 \mathrm{~mm} \phi\end{array}$ \\
\hline No. 4 & スパイラルロープ & $1+6+12$ & 150 & 68.26 & $\begin{array}{l}10 \mathrm{~mm} \phi \\
(メ ッ キ)\end{array}$ \\
\hline
\end{tabular}

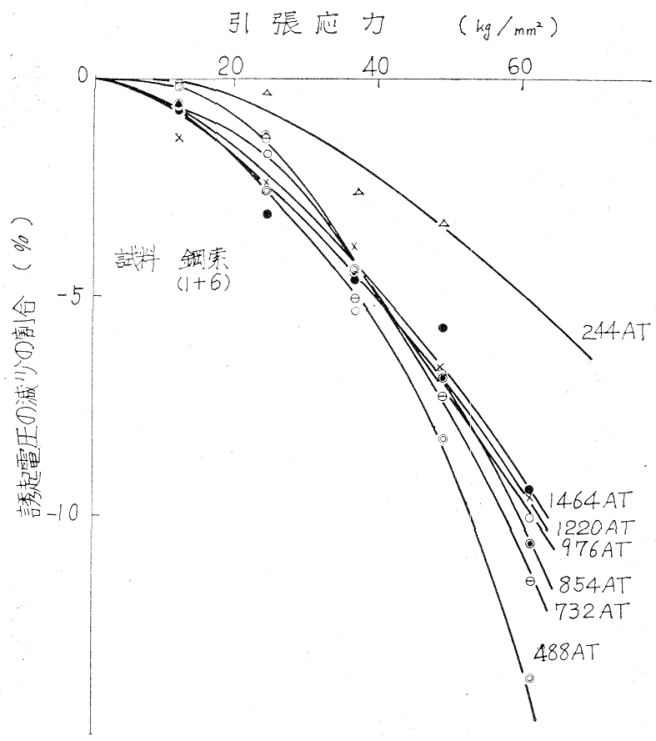

第 3 図 引张応力汇上る誘起電圧の変化

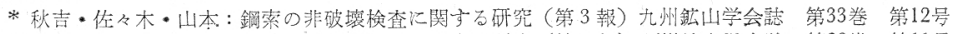

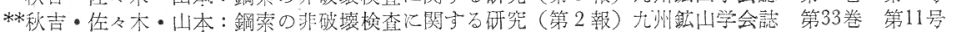




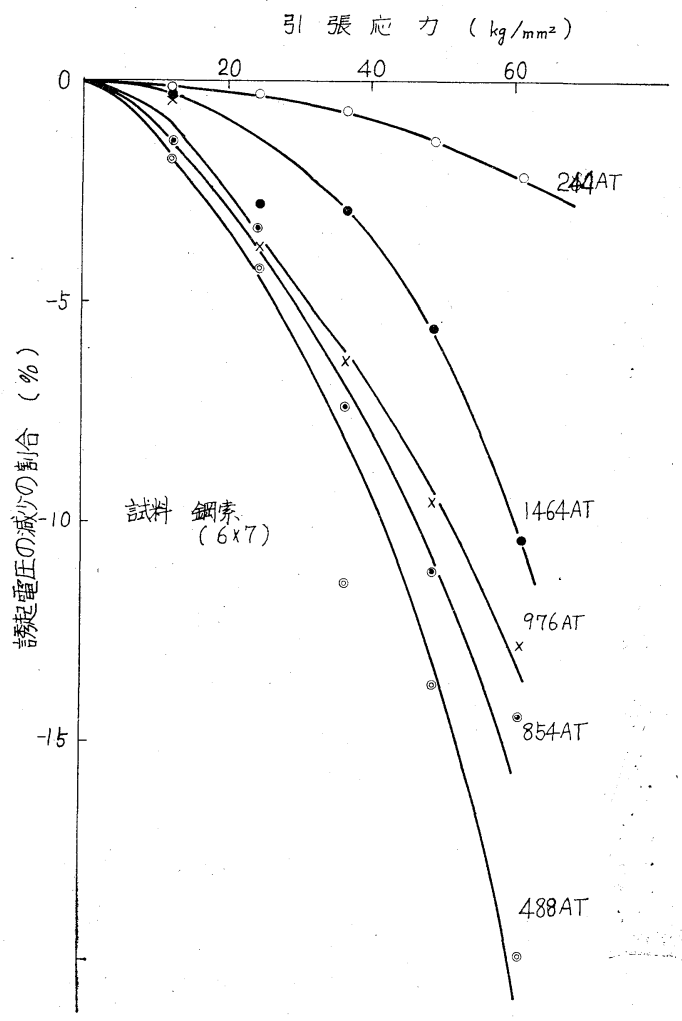

第 4 図引張応力による誘起電圧の変化

の各図に示めした。

この三例を比較してNo. 2 (第 3 図) とNo. 3(第 4 図) は類似の線材であるが，No. 2 の減少の割合が少ないこ とは撚りの少ない影響と考えられる。つぎに，No. 4(第 5 図）が No. 2 より減少の割合が大きいことは撚りの影 響と岸素の含有量の少ないためによるとみなされる。

さらに, No. 3 の $6 \times 7,14 \mathrm{~mm} \phi$ について, 張力有無 のヒステリシス環線を第 6 図 (A) 有, (B)無に示めし た。これによると張力による磁束の減少が $(\mathrm{A}<\mathrm{B})$ み られる。

以上のように探賃を行なう鋼索に張力が作用すると， 誘起電圧は減少する。したがつて, 張力が作用している 状態で検查する場合断面積が減少している部分ではそれ

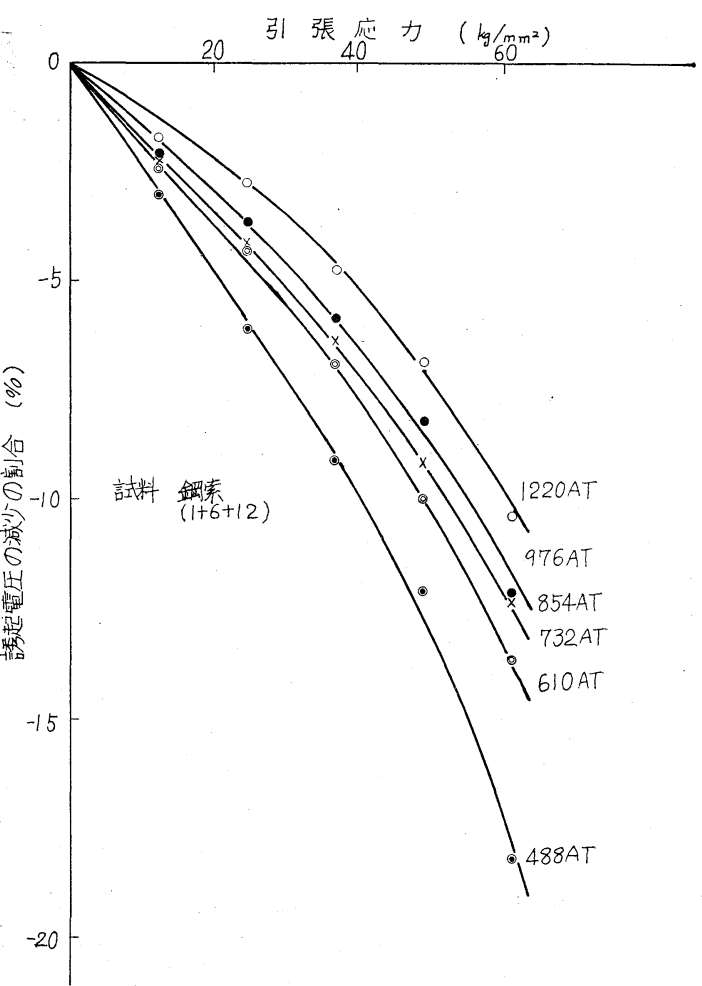

第 $\mathbf{5}$ 図 引張応力とよる誘起電圧の変化

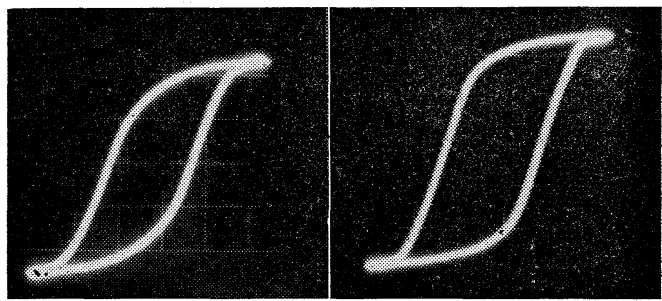

(A) $61.3 \mathrm{~kg} / \mathrm{mm}^{2}$

(B) $0 \mathrm{~kg} / \mathrm{mm}^{2}$

試料 $6 \times 7,14 \mathrm{~mm} \phi$

第 6 図 応力によるヒステリシス環線の変化

だけ応力が大きくなるので拡大検出される。それゆえ応 力の影響に対する補正が必要になる。

\section{2 ワイヤロープの特 性 試 験}

$$
\begin{array}{rrcc}
\text { 帝国産業株式会社専務取締役・工博 } & \text { 西 } & \text { 岡 } & \text { 多三 郎(正会員) } \\
\text { 帝国産業株式会社研究開発部 } & \bigcirc \text { 西 } & \text { 岡 } & \text { 猛 }
\end{array}
$$

\section{1.'緒言}

ロープのキンクは著者の一人がすでに発表したと打り ロープの切断荷重を極度に低下させるが，このキンクの 生成はロープのうねり特性と密接な関係がある。ロープ
のらねりはキンク生成のほか，ロープの性質を劣化させ 使用上幾多の欠陌を生ぜしめるためうねりの予防, 除去 が重要な問題となつてきた。しかし従来はうねり特性の 精確な測定方法がなく, 観測者の感に頼つているこそか 多かつた。特にうねり度合の小さい場合はその測定值に 